\title{
Antagonistic Activities of Bacillus spp. Strains Isolated from Tidal Flat Sediment Towards Anthracnose Pathogens Colletotrichum acutatum and C. gloeosporioides in South Korea
}

\author{
Joon-Hee Han ${ }^{1}$, Hongsik Shim ${ }^{2}$, Jong-Hwan Shin ${ }^{1}$ and Kyoung Su Kim ${ }^{1,3 *}$ \\ ${ }^{1}$ Applied Biology Program, Division of Bioresource Sciences, Kangwon National University, Chuncheon 200-701, Korea \\ ${ }^{2}$ Crop Protection Division, National Academy of Agricultural Science, Rural Development Administration, Wanju-gun 565- \\ 851, Korea \\ ${ }^{3}$ BioHerb Research Institute, Kangwon National University, Chuncheon 200-701, Korea
}

(Received on March 15, 2015; Revised on April 14, 2015; Accepted on April 15, 2015)

\begin{abstract}
Anthracnose is a fungal disease caused by Colletotrichum species that is detrimental to numerous plant species. Anthracnose control with fungicides has both human health and environmental safety implications. Despite increasing public concerns, fungicide use will continue in the absence of viable alternatives. There have been relatively less efforts to search antagonistic bacteria from mudflats harboring microbial diversity. A total of $\mathbf{4 2 0}$ bacterial strains were isolated from mudflats near the western sea of South Korea. Five bacterial strains, LB01, LB14, HM03, HM17, and LB15, were characterized as having antifungal properties in the presence of $C$. acutatum and $C$. gloeosporioides. The three Bacillus atrophaeus strains, LB14, HM03, and HM17, produced large quantities of chitinase and protease enzymes, whereas the $B$. amyloliquefaciens strain LB01 produced protease and cellulase enzymes. Two important antagonistic traits, siderophore production and solubilization of insoluble phosphate, were observed in the three B. atrophaeus strains. Analyses of disease suppression revealed that LB14 was most effective for suppressing the incidence of anthracnose symptoms on pepper fruits. LB14 produced antagonistic compounds and suppressed conidial germination of $C$. acutatum and $C$. gloeosporioides. The results from the present study will provide a basis for developing a reliable alternative to fungicides for anthracnose control.
\end{abstract}

Keywords : antifungal activity, Bacillus atrophaeus, biological control, Colletotrichum, mudflat

*Corresponding author.

Phone) +82-33-250-6435, FAX) +82-33-259-5558

E-mail) kims@kangwon.ac.kr
Pepper (Capsicum annuum L.) is an economically very important crop. In the last decade, production of pepper increased by $40 \%$ (Kim et al., 2014). South Korea produced about 117,800 tons of pepper from approximately 45,400 hectares in 2013 (KOSTAT, 2013). Fungal species in the genus Colletotrichum cause anthracnose on many vegetables and fruits, including peppers. Anthracnose has been responsible for an estimated $10 \%$ annual reduction in pepper productivity, equivalent to about US \$100 million, in South Korea (Kim et al., 2008). In the 1990s, anthracnose symptoms on pepper was reported to be caused by $C$. gloeosporioides, C. dematium, and $C$. coccodes, with $C$. gloeosporioides representing up to $90 \%$ of the Colletotrichum spp. field population (Park and Kim, 1992). Since that time, a more aggressive form of anthracnose disease, occurring at all stages of pepper development, has reportedly been caused by C. acutatum. Colletotrichum acutatum can also infect other crops, including tomatoes (Solanum lycopersicum L.), strawberries (Fragaria ananarsa), and apples (Malus domestica), whereas C. gloeosporioides has frequently been associated with anthracnose on other fruit and vegetable crops including apple, tangerine (Citrus tangerine), persimmon (Diospyros spp.), grape (Vitis spp.), strawberry, watermelon (Citrullus lanatus), and ginseng (Panax spp.) in South Korea (Kim and Nam, 1999).

Anthracnose is usually controlled with application of chemical fungicides such as benomyl, maneb, chlorothalonil, and mancozeb (Mahoney and Tattar, 1980). Increased use of chemical fungicides has led to the development of fungicide-resistant fungal strains (Howarth and Francis 1991; Peres et al., 2004). In particular, C. acutatum is resistant to benomyl and other benzimidazole fungicides (Peres et al., 2004). Molecular analysis revealed that amino acid substitutions in $\beta$-tubulin conferred this resistance to the 
benzimidazole fungicides (Jung and Oakley, 1990). The use of pesticides continues to increase public concerns over risks associated with hazardous residues on agricultural products (Jang et al., 2010), long-term and unknown effects on health (Miles and Frewer, 2001), and adverse effects on biotic diversity in ecosystems (Kegley et al., 1999). Disease control by pesticide application is unaffordable in developing countries (Wesseling et al., 1997). For these reasons, biological control using antagonistic microorganisms has emerged as an environmentally friendly alternative for plant pathogen control (Pal and Gardener, 2006).

Antagonistic microorganisms produce a wide variety of antimicrobial metabolites (Keel et al., 1992; Ongena and Jacques, 2008; Raaijmakers et al., 2002). Plant growth promoting rhizobacteria (PGPR), a group of plant-beneficial bacteria in the rhizosphere, are antagonistic to plant pathogens by producing secondary metabolites, including siderophores, lytic enzymes, antibiotics, and cyanide (Chet et al., 1990; Than et al., 2004). Although PGPR properties responsible for plant growth promotion have not been fully elucidated, PGPR is known to produce plant growth regulators such as indole-3-acetic acid (IAA) and promote asymbiotic $\mathrm{N}$ fixation and solubilization of soil $\mathrm{P}$ compounds (Idris et al., 2007; Malik et al., 1997; Rodriguez and Fraga, 1999). Antagonistic microorganisms include Bacillus spp., Pseudomonas spp., Paenibacillus spp., and Streptomyces spp., which are mainly isolated to control the pepper anthracnose from the rhizosphere and plant microflora (Garbeva et al., 2004; Jeon et al., 2010; Lamsal et al., 2012; Lee et al., 2011; Lim, 2005; Weller, 2007; Yoo et al., 2012). However, there is wide range of environments where more beneficial microorganisms have not been discovered.

Tidal flats on coastlines and on the shores of lagoons and estuaries in intertidal areas are highly productive, as they support microbial growth with an abundance of organic matter (Kim et al., 2004). We isolate antagonistic bacterial strains from tidal flats and determine their antagonistic properties by investigating the production of compounds including siderophores, proteases, and chitinases, and their ability to solubilize insoluble phosphatase. In addition, antagonistic activities of selected bacteria were evaluated in the presence of fungal pathogens $C$. acutatum and $C$. gloeosporioides by measuring suppression of growth, germination, and disease severity.

\section{Materials and Methods}

Isolation of bacterial strains. Soil samples were collected from mudflats on the west coast of Youngjongdo $\left(37^{\circ} \mathrm{N}\right.$. lat., $126^{\circ}$ E. long) in South Korea, placed in sterilized poly- thene bags, brought to the laboratory, and stored at $4^{\circ} \mathrm{C}$. To isolate bacterial strains from the mudflats, $1 \mathrm{~g}$ of mudflat sample was mixed with $9 \mathrm{ml}$ sterile water. The mudflat suspensions were serially diluted with sterile water, after which a $1 \mathrm{ml} 10^{-5}$ dilution was plated on LB agar (trytone $1 \%$, yeast extract $0.5 \%, \mathrm{NaCl} 0.5 \%$, agar $1.5 \%$ ) and marine agar (Difco, Detroit, MI, USA) plates. The plates were incubated at $28^{\circ} \mathrm{C}$ for 3 days, after which colonies were sub-cultured onto a new plate of the same media to isolate single colonies. The isolated bacterial strains were stored in LB containing $20 \%$ glycerol at $-70^{\circ} \mathrm{C}$.

Identification of bacterial isolates. DNA was extracted from the bacterial cells by harvesting $3 \mathrm{ml}$ cells following overnight culture. Chromosomal DNA was extracted using a Wizard genomic DNA purification kit (Promega, USA). The 16S rRNA was amplified with the universal primers 27F (AGAGTTTGATCMTGGCTCAG), 1492R (TACGGYTACCTTGTTACGACTT), in Thermal Cycler Thermal Controller 2720 (Applied Biosystems, USA). PCR products were purified using a fragment DNA purification kit (Intron, Korea), and were subsequently sequenced using primers 518F (CCAGCAGCCGCGGTAATACG) and 800R (TACCAGGGTATCTAATCC; Macrogen Inc., Seoul, Korea). The sequences were blasted against the BLASTN program of NCBI (http://blast.ncbi.nlm.nih.gov/ Blast.cgi). DNA sequences from the NCBI nucleotide database were aligned with the ClustalW program in MEGA 6.0, and the phylogenetic relationship was constructed using the nearest-neighbor data analysis method with 1,000 bootstrap replicates.

Assays for inhibition of hyphal growth and conidial germination. Antifungal activity was imposed on a PDA plate with holes (4 $\mathrm{mm}$ in diameter) punched using a cork borer. Bacterial strains were inoculated 1 day before inoculation of the fungal pathogens, and $20 \mu \mathrm{l}$ bacteria culture were dropped into the holes. All of the cultures were incubated at $25^{\circ} \mathrm{C}$ in the dark. The growth of fungal pathogens was evaluated 10 days after incubation. Inhibition of fungal growth was measured as the distance of the clear zone between the bacterial colony and each fungus according to the following formula:

$$
\text { Inhibition of growth }(\%)=(1-\mathrm{TD} / \mathrm{CD}) \times 100
$$

where TD and CD were the distance between the center and fungal hyphae edges in the treatment and control plates, respectively. Each experiment was replicated three times, and three separate experiments were performed.

For conidial germination assay, Collectorichum species 
were incubated on PDA plates at $25^{\circ} \mathrm{C}$, and conidia production was induced. After 10 days, conidia were harvested with distilled water. Conidial suspension concentration was adjusted to $1 \times 10^{4}$ conidia/ml using a hemocytometer. Each bacterial culture (OD 1.0) diluted serially (10, 100, and 1000 times) was co-mixed with the conidial suspension, placed on a hydrophobic slide (Knittel Glaser, Germany), and incubated at $25^{\circ} \mathrm{C}$ in a humidity box for $20 \mathrm{~h}$. Inhibition rate of conidial germination was calculated, according to the following formula (Kwak et al., 2012):

Inhibition rate of conidial germination $(\%)=(1-\mathrm{T} / \mathrm{C}) \times 100$

where $\mathrm{T}$ represented germination rate of the treatment, and $\mathrm{C}$ represented germination rate of the control. Each experiment was replicated three times, and three separate experiments were conducted.

Analyses of antimicrobial and antagonistic substances. Chitin degrading ability was tested in colloidal chitin agar media containing $0.7 \mathrm{~g} / 1 \mathrm{~K}_{2} \mathrm{HPO}_{4}, 0.3 \mathrm{~g} / 1 \mathrm{KH}_{2} \mathrm{PO}_{4}, 0.5 \mathrm{~g} /$ $1 \mathrm{MgSO}_{4} \cdot 5 \mathrm{H}_{2} \mathrm{O}, 0.01 \mathrm{~g} / 1 \mathrm{FeSO}_{4} \cdot 7 \mathrm{H}_{2} \mathrm{O}, 0.001 \mathrm{~g} / 1 \mathrm{ZnSO}_{4}$, $0.001 \mathrm{~g} / 1 \mathrm{MnCl}_{2}, 15 \mathrm{~g} / \mathrm{l}$ agar, and $0.5 \mathrm{~g}$ colloidal chitin dissolved in 11 distilled water (Hsu and Lockwood, 1975). Colloidal chitin was prepared as follows. Chitin powder 80 $\mathrm{g}$ was dissolved in $1 \mathrm{~L}$ concentrated hydrochloric acid and continuously stirred on ice for $1 \mathrm{~h}$. After stirring, the hydrolyzed chitin was washed several times with distilled water to remove the acid, using filter paper, after which $\mathrm{pH}$ was adjusted to a range of 6-7. This colloidal chitin was stored as a paste at $4^{\circ} \mathrm{C}$. After incubation for 3 days at $25^{\circ} \mathrm{C}$, development of a clear zone indicated chitinase activity.

Proteolytic activity was tested by LB agar plates containing with 3\% skim milk powder (Sokol et al., 1979). After 3 days incubation at $28^{\circ} \mathrm{C}$, clear zone surrounding the bacterial suggested protease production.

Screening for cellulase producers was conducted on CMC agar $\left(1.0 \mathrm{~g} / 1 \mathrm{KH}_{2} \mathrm{PO}_{4}, 0.5 \mathrm{~g} / 1 \mathrm{MgSO}_{4} \cdot 7 \mathrm{H}_{2} \mathrm{O}, 0.5 \mathrm{~g} /\right.$ $1 \mathrm{NaCl}, 0.01 \mathrm{~g} / 1 \mathrm{FeSO}_{4} \cdot 7 \mathrm{H}_{2} \mathrm{O}, 0.01 \mathrm{~g} / \mathrm{MnSO}_{4} \cdot \mathrm{H}_{2} \mathrm{O}, 0.3$ $\mathrm{g} \mathrm{NH} \mathrm{NO}_{3}, 10 \mathrm{~g} / 1$ carboxymethyl cellulose, $12 \mathrm{~g} / \mathrm{l}$ agar) media (Teather and Wood, 1982). After incubation at $25^{\circ} \mathrm{C}$ for 3 days, the agar was flooded with $0.1 \%$ Congo red for $15 \mathrm{~min}$ to $20 \mathrm{~min}$, and then with $1 \mathrm{M} \mathrm{NaCl}$ for $15 \mathrm{~min}$ to $20 \mathrm{~min}$. After staining, agar plates were observed for zones around the colonies.

Phosphate solubilization screening was performed on Pikovskaya's media (Nautiyal, 1999) containing $10 \mathrm{~g} / 1$ glucose; $5 \mathrm{~g} / 1 \mathrm{Ca}_{3}\left(\mathrm{PO}_{4}\right)_{2}, 0.5 \mathrm{~g} / 1\left(\mathrm{NH}_{4}\right)_{2} \mathrm{SO}_{4}, 0.2 \mathrm{~g} / 1 \mathrm{NaCl}, 0.1$ $\mathrm{g} / 1 \mathrm{MgSO}_{4} \cdot 7 \mathrm{H}_{2} \mathrm{O}, 0.1 \mathrm{~g} / 1 \mathrm{KCl}, 0.2 \mathrm{~g} / 1$ yeast extract, 0.001 $\mathrm{g} / 1 \mathrm{MnSO}_{4} \cdot \mathrm{H}_{2} \mathrm{O}$, and $0.001 \mathrm{~g} / 1 \mathrm{FeSO}_{4} \cdot 7 \mathrm{H}_{2} \mathrm{O}$. The $\mathrm{pH}$ of the media was adjusted to 6.8 before autoclaving. After incubation for 15 days at $25^{\circ} \mathrm{C}$, the development of a clear zone indicated phosphate solubilization.

Siderophore production was measured using the modified Chrome azurol S (CAS) agar assay (Schwyn and Neilands, 1987). CAS agar plate was prepared as follows. A total of $60 \mathrm{mg}$ CAS was dissolved in $50 \mathrm{ml}$ deionized water and mixed with $10 \mathrm{ml}$ iron (III) solution $\left(2.7 \mathrm{mg} \mathrm{FeCl} \cdot 6 \mathrm{H}_{2} \mathrm{O}\right.$, $10 \mathrm{mM} \mathrm{HCl}$ ). This solution was slowly mixed with $73 \mathrm{mg}$ HDTMA dissolved in $40 \mathrm{ml}$ water. The resulting blue dye solution was autoclaved and mixed with a solution of 750 ml, $15 \mathrm{~g} / \mathrm{l}$ agar, $32.24 \mathrm{~g} / \mathrm{l}$ PIPES, and $100 \mathrm{ml} \mathrm{MM9} \mathrm{salt}$ stock solution $\left(30 \mathrm{~g} / 1 \mathrm{KH}_{2} \mathrm{PO}_{4}, 50 \mathrm{~g} / 1 \mathrm{NaCl}, 100 \mathrm{~g} / 1 \mathrm{NH}\right.$ in $11 \mathrm{ddH}_{2} \mathrm{O}$ ). This solution was autoclaved and cooled to $50^{\circ} \mathrm{C}$, to which we slowly added $100 \mathrm{ml}$ blue dye, $30 \mathrm{ml}$

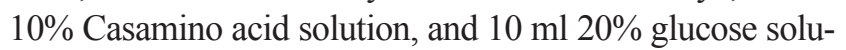
tion along the glass wall, with sufficient agitation to mix thoroughly. The modified CAS agar plate was punched with $4 \mathrm{~mm}$ diameter holes using a cork borer. Each hole was filled with a $20 \mu \mathrm{l}$ of bacterial suspension. LB broth was used as the negative control. Siderophore production was measured after 5 days of incubation at $25^{\circ} \mathrm{C}$.

Disease suppression assay. For the pathogenicity assay, pepper fruits were surface sterilized for $1 \mathrm{~min}$ in $1 \% \mathrm{NaO}-$ $\mathrm{Cl}$, briefly rinsed with distilled water, and air-dried at room temperature. Each bacterial culture suspension (1.0 O.D) was sprayed. After $24 \mathrm{~h}$, a C. acutatum spore suspension $\left(3.5 \times 10^{4}\right.$ conidia $\left./ \mathrm{ml}\right)$ was inoculated on pepper fruits, and incubated at room temperature in a humidity box. After 2 weeks, the diseased areas of pepper fruits were measured visually and by image assessment with computer programs (ImageJ $1.48 \mathrm{~V}$ ).

Biochemical and physiological characteristics. Analytical profile indices (APIs) from kit API 50CHB systems (BioMérieux, Marcy l'Etoile, France) were used to characterize the physiological and biochemical properties of the bacterial isolates. API panel test system substrate utilization tests were performed using the API 50CHB systems panel. API test strips were handled according to the manufacturer's instructions (bioMerieux, Marcy l'Etoile, France). Stock cultures were streaked onto LB agar to obtain single colonies for each bacterial isolate. Bacterial colonies of each isolate were diluted in $0.85 \% \mathrm{NaCl}$ solution. The amount of bacteria was adjusted to $1 \mathrm{McF}$ arland, and 200 $\mathrm{ml}$ of this solution was transferred into each well of the panels. To prevent contamination from the air, the wells were filled with mineral oil, and incubated at $25^{\circ} \mathrm{C}$. Readings were recorded after $48 \mathrm{~h}$. 


\section{Results}

Antifungal activity and identification of bacterial strains. Soil samples from mudflats of the western sea of South Korea were used to isolate bacteria with antifungal properties. A total of 420 bacteria species were isolated and categorized into 13 groups, based on colony morphology and pigmentation. A representative member of each group was screened for antifungal activity against $C$. acutatum and $C$. gloeosporioides using a dual culture method.

As shown in Fig. 1A, five bacteria strains inhibited growth of $C$. acutatum and C. gloeosporioides. The strain LB01 exerted the highest inhibition of mycelial growth on C. acutatum (60.15\%) and C. gloeosporioides (58.12\%) compared to the control (Fig. 1B, C). The strain LB14 showed $59.29 \%$ and $53.87 \%$ inhibition of mycelial growth of $C$. acutatum and $C$. gloeosporioides, respectively. HM03 and HM17 also inhibited mycelial growth of $C$. acutatum and $C$. gloeosporioides by more than $50 \%$. The strain LB15 was the least effective among the five strains in inhibiting mycelial growth of the two fungal species.

To identify the five strains with antifungal activity, their 16S rRNA sequences were analyzed. Sequence data revealed that the five bacterial isolates belonged to the Bacillus or Staphylococcus genus (Table 1). The three strains, LB14, HM03, and HM17, were distantly related and grouped with B. atrophaeus. The two strains, LB01 and LB15, were very closely grouped with $B$. amyloliquefaciens and B. pumilus, respectively (Fig. 2).

Production of antimicrobial and antagonistic substances. To examine antifungal activity of the isolated Bacillus species, they were tested for production of antimicrobial substances, including chitinase, protease, and cellulase, on LB plates containing colloidal chitin, skim milk, or carboxymethyl cellulose (Fig. 3A). Three strains, LB14, HM03, and HM17, were able to decompose chitin, but LB01 and LB15 were unable to degrade chitin. Strong pro-

\section{A}
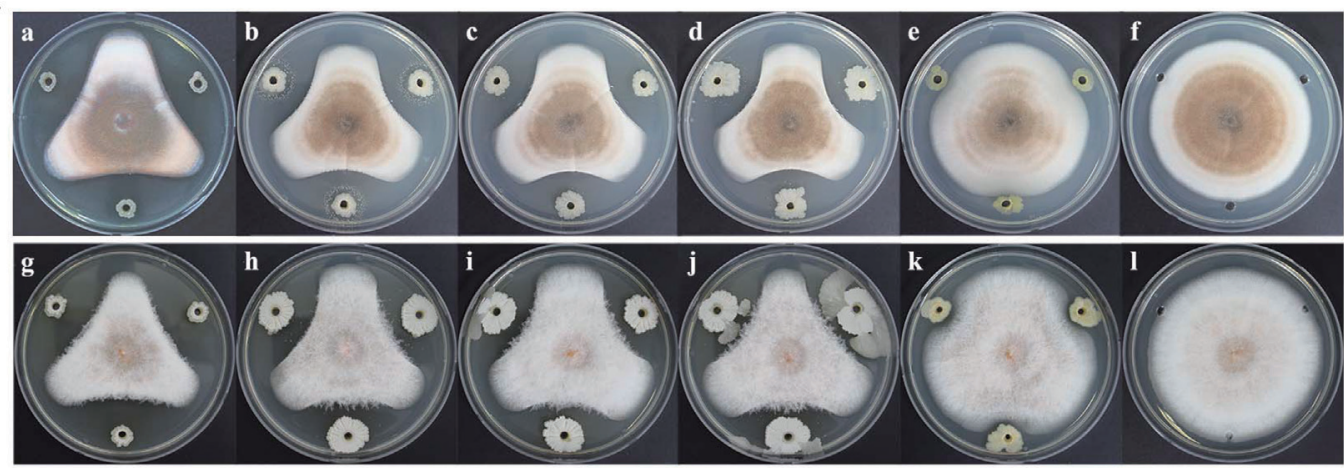

B

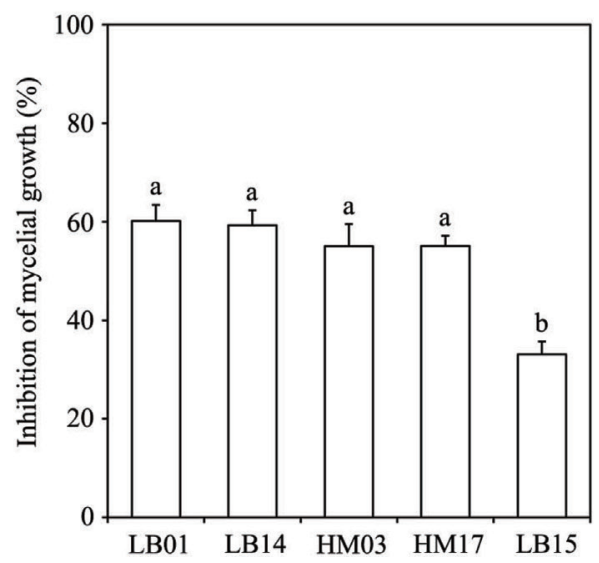

C

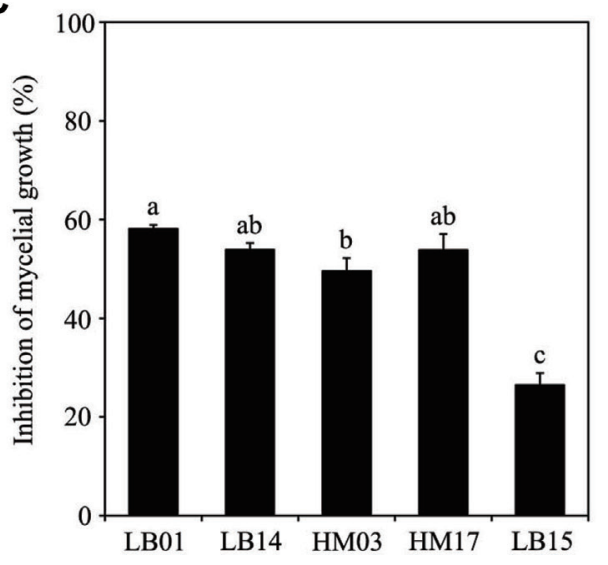

Fig. 1. Antifungal activity of bacterial isolates taken from mudflat soil samples of the western sea of Korea. (A) Dual culture assay for in vitro inhibition of mycelial growth of C. acutatum and C. gloeosporioides by bacterial isolates. The fungal pathogens (C. acutatum; upper panel, C. gloeosporioides; lower panel) were co-cultured with bacterial isolates LB01 (a, g), LB14 (b, h), HM03 (c, i), HM17 (d, j), LB15 (e, k). Controls (f, l) were without bacterial cells. Measurement of inhibitory effects of bacterial isolates on mycelial growth of $C$. acutatum (B) and C. gloeosporioides (C). Error bars represent standard deviations over three replicates. Different letters on bars indicate significant differences according to Duncan's multiple range test at $p=0.05$. 
Table 1. Identification of bacterial isolates to species based on 16S rRNA sequences

\begin{tabular}{cccc}
\hline Isolate & Species & GenBank accession No. & Similarity (\%) \\
\hline LB01 & Bacillus amyloliquefaciens & KJ572221.1 & 99 \\
LB14 & Bacillus atrophaeus & KJ469797.1 & 99 \\
LB15 & Bacillus pumilus & KF601954.1 & 99 \\
LB06 & Staphylococcus pasteuri & AJ717376.1 & 99 \\
HM01 & Staphylococcus cohnii & HG941657.1 & 99 \\
HM03 & Bacillus atrophaeus & AY881241.1 & 99 \\
HM15 & Staphylococcus warneri & KF751643.1 & 99 \\
HM17 & Bacillus atrophaeus & & 99 \\
\hline
\end{tabular}

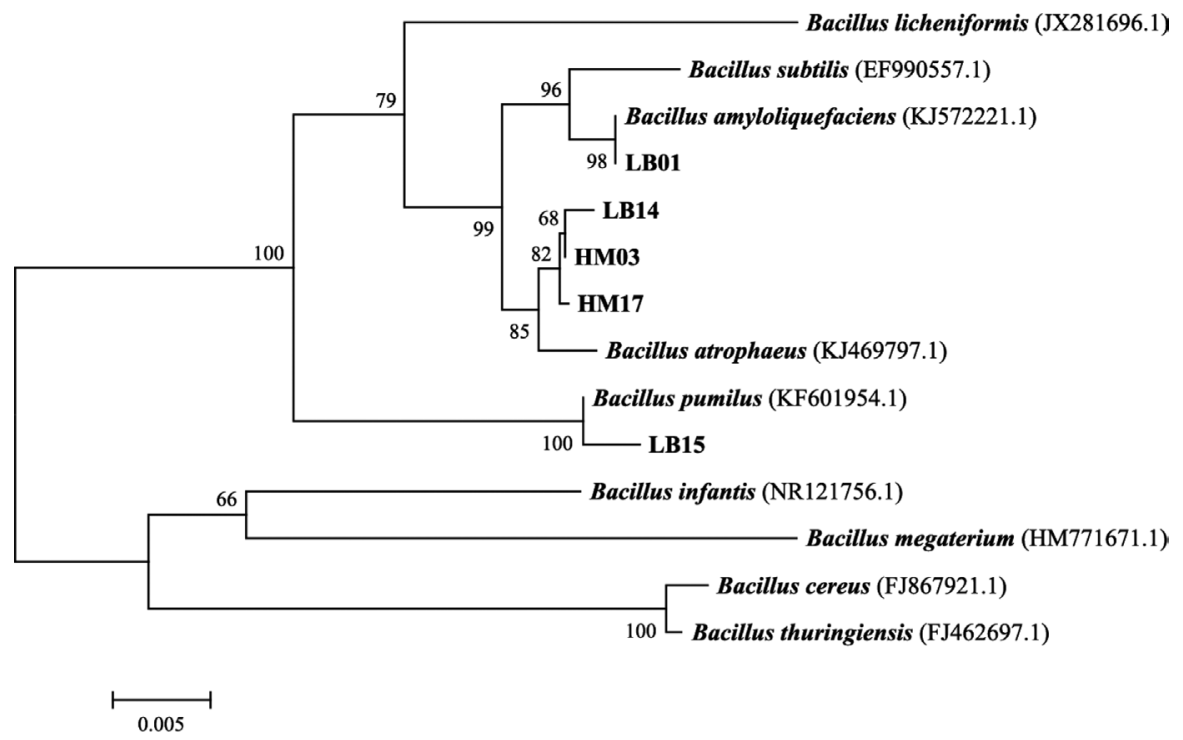

Fig. 2. Phylogenetic relationship based on $16 \mathrm{~S}$ rRNA sequences of bacterial isolates with antifungal activity. DNA sequences from the NCBI nucleotide database were aligned using the ClustalW program in MEGA 6.0, and constructed using the neighbor-method with 1,000 bootstrap replicates. The scale bar indicates the number of differences in nucleotide substitutions per sequences. The GenBank accession numbers of the Bacillus species most similar to the bacterial isolates were indicated in parenthesis.

teolytic activity was found in LB01, LB14, HM03, HM17, and LB01. LB15 formed a very faint zone, suggesting less proteolytic activity. Strong cellulase activity was observed for LB01. LB14, HM03, and HM17 had no cellulase activity.

As a next step, we determined the contribution of siderophore production and solubilization of insoluble phosphate to antagonistic properties of the isolated Bacillus species (Fig. 3B). All of the tested strains formed halo zones on CAS agar media, indicating strong siderophore production. Among the five strains, LB14, HM03, and LB15 had relatively higher siderophore production. The highest solubilization capacity of insoluble phosphate was found for LB14, HM03, and HM17.

Suppression of conidial germination of $C$. acutatum and C. gloeosporioides by Bacillus strains. Because conidial germination is an early stage of disease development, the ability of Bacillus strains to suppress conidial germination of $C$. acutatum and C. gloeosporioides was investigated (Fig. 4). Ten-fold diluted cultures of the other four strains, LB01, LB14, HM03, and HM17, highly suppressed conidial germination of $C$. acutatum (Fig. 4A) and C. gloeosporioides (Fig. 4B). Cultures of LB15 were not effective for suppressing conidial germination of C. acutatum, although the culture at a 10-fold dilution exhibited increased effectiveness on suppression of conidial germination of $C$. gloeosporioides. All of the serial dilution cultures of LB14 strongly inhibited conidial germination of both C. acutatum and C. gloeosporioides. HM03 cultures diluted to 10-fold and 100-fold effectively inhibited conidial germination of the two fungal isolates. Effectiveness of the HM03 culture diluted 1000 -fold dropped to $29 \%$ in inhibiting conidial 


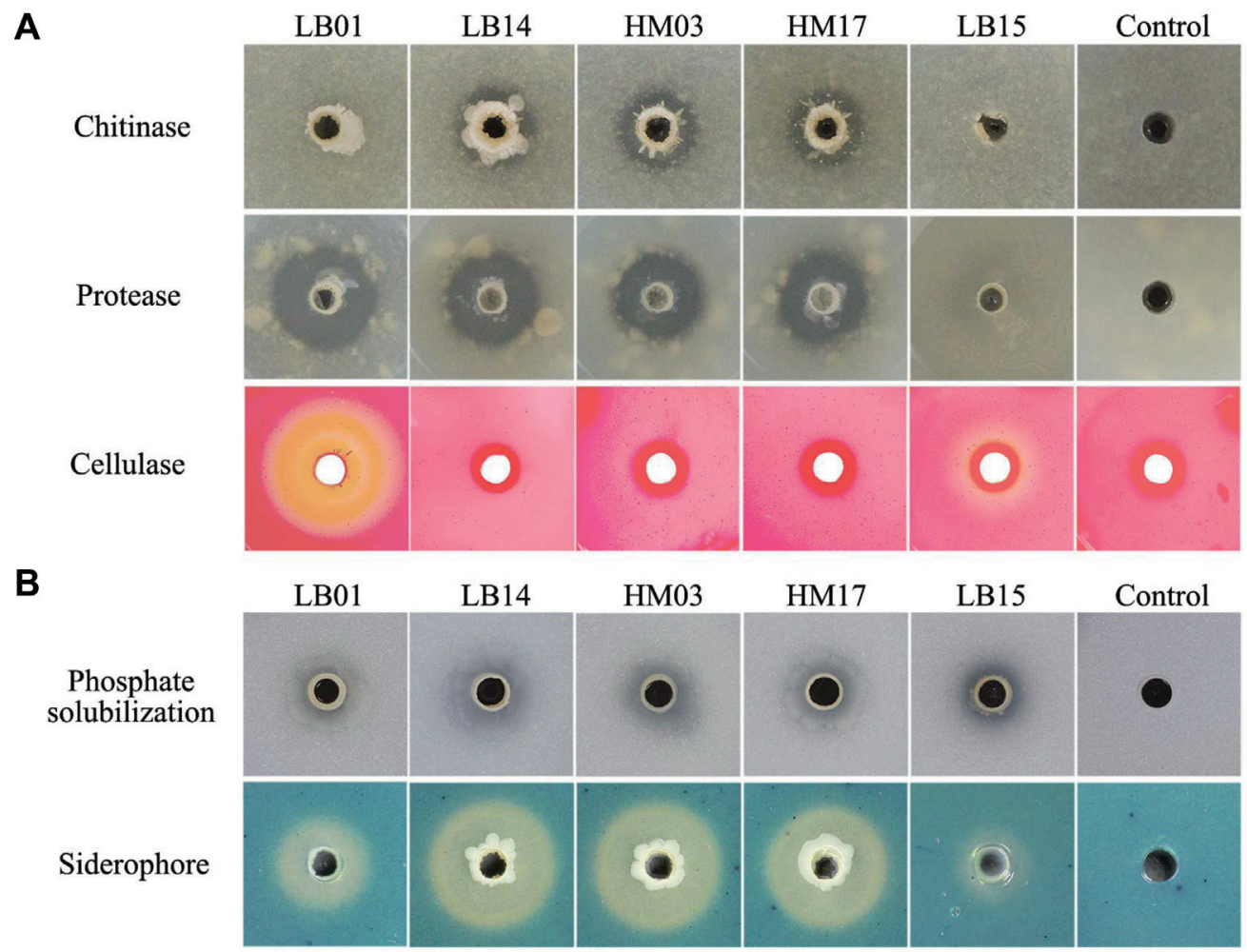

Fig. 3. Characterization of antagonistic substances produced by Bacillus strains. (A) Production of chitinase, protease, and cellulase by Bacillus strains. Production of chitinase was examined on colloidal chitin agar plates including $0.05 \%$ colloidal chitin. Protease production was examined on LB plates containing 3\% skim milk. Cellulase production was examined on CMC agar plates containing $1.2 \%$ carboxymethyl cellulose, followed by flooding with $0.1 \%$ congo red solution. (B) Siderophore production and phosphate solubilization by Bacillus strains. Siderophore production and solubility capacity of phosphate were examined on chrome azurol S (CAS) agar plates and Pikovskaya's agar plates, respectively.
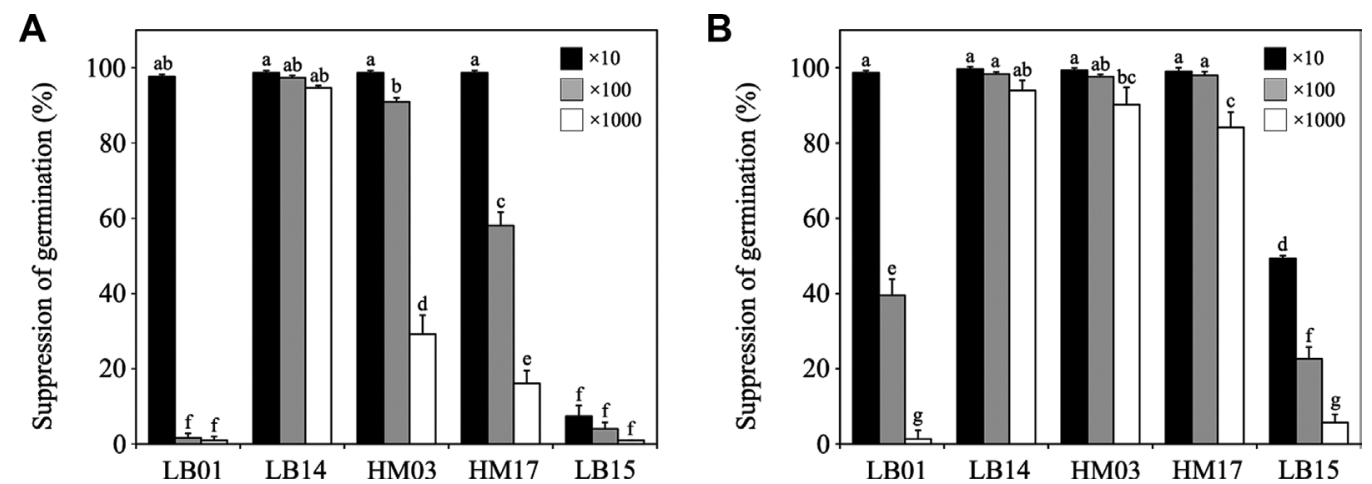

Fig. 4. Suppression of conidial germination of Colletotrichum species by Bacillus strains. (A) Suppression of conidial germination of $C$. acutatum. (B) Suppression of conidial germination of $C$. gloeosporioides. Error bars represent standard deviations over three replicates. Different letters on bars indicate significant differences according to Duncan's multiple range test at $p=0.05$.

germination of C. acutatum, but it was stable in inhibiting germination of $C$. gloeosporioides. Clear differences were found in the ability of serial dilutions of HM17 cultures to inhibit conidial germination of $C$. acutatum compared to $C$. gloeosporioides.

We also tested the ability of Bacillus strains to suppress C. acutatum-mediated disease development on peppers. As shown in Fig. S1 and Table 2, diseased areas on pep- 
Table 2. Control efficiency of bacterial strains against $C$. acutatum on pepper

\begin{tabular}{ccc}
\hline Treatment & Diseased area $(\%)^{\mathrm{a}}$ & Control efficiency (\%) \\
\hline LB01 & $5.3 \pm 4.3 \mathrm{a}^{\mathrm{b}}$ & 94.0 \\
LB14 & $2.9 \pm 2.4 \mathrm{a}$ & 96.7 \\
HM03 & $9.1 \pm 7.2 \mathrm{a}$ & 89.7 \\
HM17 & $5.2 \pm 5.6 \mathrm{a}$ & 94.2 \\
LB15 & $45.9 \pm 16.4 \mathrm{~b}$ & 48.1 \\
Fungicide $^{\mathrm{b}}$ & $2.8 \pm 0.7 \mathrm{a}$ & 96.8 \\
Control & $88.6 \pm 2.7 \mathrm{c}$ & - \\
\hline
\end{tabular}

${ }^{a}$ Values are means \pm standard errors, calculated from three independent observations. Those sharing the same letter are not significantly different, based on the Duncan's multiple range test at $p=0.05$.

${ }^{b}$ The fungicide used is pyraclostrobin.

pers were significantly reduced with treatment of Bacillus strains. Diseased areas ranged from $2.9 \%$ to $45.9 \%$ on $\mathrm{Ba}$ cillus-treated peppers, whereas the diseased area occupied $88.6 \%$ of Bacillus-untreated peppers (control). The highest suppression of pepper anthracnose disease was found on LB14-treated peppers with $96.7 \%$ control efficiency.

Biochemical and physiological characterization of the LB14 strain. Based on antagonistic effects and the ability to suppress anthracnose, LB14 was selected for biochemical and physiological characterization (Table 3). This analysis revealed that LB14, identified as B. atrophaeus, was able to fully metabolize glycerol, L-arabinose, ribose, D-glucose, D-fructose, D-mannose, D-manitol, L-sorbitol, arbutin, esculin, salicin, cellobiose, sucrose, and trehalose. Unlike B. subtilis, LB14 was unable to metabolize Dxylose, inulin, and gluconate, suggesting that LB14 differs from $B$. subtilis in utilization of carbohydrates.

\section{Discussion}

In recent years, there has been increasing demand for safe and eco-friendly agricultural products (Huh and Kim, 2010). Accordingly, biological control practices are in much greater demand as alternatives to synthetic pesticides. Biological control practices are particularly important in organic crop production disease control (Cook, 1993; Han et al., 2013; Kim and Yun, 2011; Yang et al., 2002).

Reports from several studies provide strong evidence that strains of Bacillus species, including B. subtilis (Kim et al., 2012; Lee et al., 2006; Lee et al., 2011), B. amyloliquefaciens (Kong et al., 2010a; Lee et al., 2013; Wu et al., 2007), B. licheniformis (Govender et al., 2005; Kim et al., 2007; Kong et al., 2010b), B. pumilus (Akhtar and Siddiqui, 2008; Sari et al., 2007), B. mycoides, and B. sphaericus, significantly reduce disease severity on a variety of hosts in greenhouse or field conditions (Kloepper et al., 2004). $B$. subtilis and $B$. amyloliquefaciens have been used in commercial biological control products due to their excellent antagonistic effects and high stability in harsh environmental conditions (Kwak et al., 2012).

In the present study, we isolated antagonistic microorganisms from tidal flat sediments, including three strains of B. atrophaeus (LB14, HM03, and HM17, one strain of B. amyloliquefaciens (LB01), and one strain of B. pumilus (LB15). A previous study used tidal flat sediments and jeotgal, a salted-fermented fish product, to find antagonistic microorganisms in Korea. The antagonistic bacteria included Paenibacillus macerans, B. atrophaeus, and B. pumilus from tidal flat sediments, and $B$. atrophaeus, Paenibacillus sp. Virgibacillus pantothenticus, B. subtilis, and other $B a-$ cillus sp. from jeotgal (Kim et al., 2010).

Consistent with previous reports that B. atrophaeus suppresses fungal plant pathogens (Kim et al., 2010), our study demonstrated that three B. atrophaeus strains, LB14, HM03, and HM17, were effective for not only inhibiting mycelial growth, but also inhibiting conidial germination of C. acutatum and C. gloeosporioides. Furthermore, we showed that chinase, protease, siderophore, and phosphate solubilization, associated with LB14, HM03, and HM17, may contribute to suppression of C. acutatum and C. gloeosporioides.

Fungal cell walls play important physiological roles, in addition to providing structural barriers, in regulating the passage of molecules into cells and their development and survival in response to ambient conditions. The fungal cell wall is a matrix composed of polysaccharides, small amounts of proteins, and other components. Many fungal pathogens in ascomycota and basidiomycota have a mixture of chitin, polymers of glucan, and mannoproteins in their cell walls (Vega and Kalkum, 2012). Many antagonistic bacteria secrete lytic enzymes capable of dissolving fungal cell walls, resulting in exhibition of predatory activity of fungal pathogens (Xu et al., 2014). Strong activity of chitinase and protease in the B. atrophaeus strains LB14, HM04, and HM17 are therefore consistent with the observed growth inhibition of C. acutatum and C. gloeosporioides (Fig. 3A).

Proteases, in particular, play a key role in the cell lysis process. Proteases bind to the outer mannoprotein layer of the cell wall, open the protein structure, and expose inner glucan layers and chitin microfibrils. Among the three $B$. atrophaeus strains, LB01 (B. amyloliquefaciens) exhibited strong protease activity. However, activity of chitinase and protease was almost absent in LB15 (B. pumulis). This 
Table 3. Biochemical and physiological characterization of the LB14 strain

\begin{tabular}{|c|c|c|c|c|c|}
\hline Substrate & LB14 & B. subtilis ${ }^{\mathrm{a}}$ & Substrate & LB14 & B. subtilis \\
\hline Glycerol & + & + & Salicin & + & + \\
\hline Ertythritol & - & - & Cellobiose & + & + \\
\hline D-arabinose & - & - & Maltose & $\Delta$ & + \\
\hline L-arabinose & + & + & Lactose & - & - \\
\hline Ribose & + & + & Melibiose & - & + \\
\hline D-xylose & - & + & Sucrose & + & + \\
\hline L-xylose & - & - & Trehalose & + & + \\
\hline D-adonitol & - & - & Inulin & - & + \\
\hline$\beta$-methyl-D-xyloside & - & - & Melezitose & - & - \\
\hline D-galactose & - & - & Raffinose & - & + \\
\hline D-glucose & + & + & Starch & - & + \\
\hline D-fructose & + & + & Glycogen & - & + \\
\hline D-mannose & + & + & Xylitol & - & - \\
\hline L-sorbose & - & - & $\beta$-gentiobiose & $\Delta$ & - \\
\hline L-rhamnose & - & - & D-turanose & - & + \\
\hline Dulcitol & - & - & D-lyxose & - & - \\
\hline Inositol & $\Delta$ & + & D-tagatose & - & - \\
\hline D-manitol & + & + & D-fucose & - & - \\
\hline L-sorbitol & + & + & L-fucose & - & - \\
\hline$\alpha$-methyl-D-mannoside & - & - & D-arabitol & - & - \\
\hline$\alpha$-methyl-D-glucoside & $\Delta$ & + & L-arabitol & - & - \\
\hline $\mathrm{N}$-acethyl-glucosamine & - & - & Gluconate & - & + \\
\hline Amygdalin & + & + & 2-keto-gluconate & - & - \\
\hline Arbutin & + & + & 5-keto-gluconate & - & - \\
\hline Esculin & + & + & & & \\
\hline
\end{tabular}

${ }^{\mathrm{a}} B$. subtilis (KACC10111) used as a control strain.

$\mathrm{b}_{+}$for fully metabolized; - for non-metabolized; $\Delta$ for some metabolized.

difference may explain the reduced effectiveness of LB15 compared to the other B. atrophaeus and B. amyloliquefaciens strains in inhibiting mycelial growth and conidial germination of $C$. acutatum and C. gloeosporioides.

The three B. atrophaeus strains, together with $B$. amyloliquefaciens and B. pumilus strains isolated from tidal flat sediments, demonstrated a high capacity to solubilize an insoluble phosphate compound. This is an important trait of antagonistic bacteria in supplying phosphate, a major nutrient required for plant growth. Uptake of phosphate by plants is limited due to low solubility of phosphate compounds in soil. Many bacteria are known to increase solubilization of insoluble phosphate forms by releasing organic acids and phosphatase enzymes (Halder et al., 1990; Rossolini et al., 1998; Sahu and Jana, 2000). Therefore, phosphate solubilizing bacteria, especially those with antifungal activities, may promote crop productivity, by not only providing plant-absorbable forms of phosphate, but also by effectively protecting plants from fungal soil-borne diseases (Dey et al., 2004; Sundara et al., 2002).

In addition, production of siderophore by the three $B$. atrophaeus strains may be a key factor in promoting plant growth and protecting plants from plant pathogens. Iron, an essential cofactor for cellular processes, is abundant in nature, but iron bioavailability is very limited in soils due to low solubility under aerobic conditions and in the presence of a neutral $\mathrm{pH}$. A number of bacteria, including plant pathogens, produce iron-chelating siderophores. Siderophores produced by antagonistic microorganisms may inhibit the growth of plant pathogens, but may enhance plant growth by increasing iron in the root zone. Studies have demonstrated that beneficial bacteria-producing siderophores stimulate plant growth and inhibit germination of a soil-borne fungal pathogen (Alexander and Zuberer, 1991; Elad and Baker, 1985; Kloepper et al., 1980). Similarly, the variable efficiency in inhibiting conidial germination of $C$. acutatum and $C$. gloeosporioides may be correlated with siderophore production by the $B$. atrophaeus and B. pumi- 
lus strains, although the effect of strong antifungal substances produced by $B$. atrophaeus strains should also be considered (Fig. 3). The B. atrophaeus strain LB14 exhibited a strong antagonistic activity and was most effective for suppressing C. acutaum-mediated disease development on pepper plants compared to the other strains (Fig. S1 and Table 2), suggesting that it may be a promising agent for biological control and plant growth promotion. Further evaluation of LB14 should be performed under different environmental conditions, cultural practices, and fungicide applications, to obtain more knowledge of efficacy in the field. Knowledge of the mechanisms and performance of antagonistic microorganisms will be helpful in developing reliable biological systems for disease control.

\section{Acknowledgments}

This study was supported by a grant (PJ00932405) from the Rural Development Administration, Republic of Korea.

\section{Conflict of Interest}

All of the authors declare that there is no conflict of interest.

\section{References}

Akhtar, M. S. and Siddiqui, Z. 2008. Glomus intraradices, Pseudomonas alcaligenes, and Bacillus pumilus: effective agents for the control of root-rot disease complex of chickpea (Cicer arietinum L.). J. Gen. Plant Pathol. 74:53-60.

Alexander, D. B. and Zuberer D. A. 1991. Use of chrome azurol $S$ reagents to evaluate siderophore production by rhizosphere bacteria. Biol. Fertil. Soils 12:39-45.

Chet, I., rdentlich, A., Shapira, R. and Oppenheim, A. 1990. Mechanisms of biocontrol of soil-borne plant pathogens by Rhizobacteria. Plant Soil 129:85-92.

Cook, R. J. 1993. Making greater use of introduced microorganisms for biological control of plant pathogens. Annu. Rev. Phytopathol. 31:53-80.

Dey, R., Pal, K., Bhatt, D. and Chauhan, S. 2004. Growth promotion and yield enhancement of peanut (Arachis hypogaea L.) by application of plant growth-promoting rhizobacteria. $M i$ crobiol. Res. 159:371-394.

Elad, Y. and Baker, R. 1985. Influence of trace amounts of cations and siderophore-producing Pseudomonads on chlamydospore germination of Fusarium oxysporum. Phytopathology 75:1047-1052.

Garbeva, P., van Veen, J. A. and van Elsas, J. D. 2004. MICROBIAL DIVERSITY IN SOIL: Selection of microbial populations by plant and soil type and implications for disease suppressiveness. Annu. Rev. Phytopathol. 42:243-270.
Govender, V., Korsten, L. and Sivakumar, D. 2005. Semi-commercial evaluation of Bacillus licheniformis to control mango postharvest diseases in South Africa. Postharvest Biol. Technol. 38:57-65.

Halder, A., Mishra, A., Bhattacharyya, P. and Chakrabartty, P. 1990. Solubilization of rock phosphate by Rhizobium and Bradyrhizobium. J. Gen. Appl. Microbiol. 36:81-92.

Han, K. S., Kim, B. R., Kim, J. T., Hahm, S. S., Hong, K. H., Chung, C. K., Nam, Y. G., Yu, S. H. and Choi, J. E. 2013. Biological control of white rot in garlic using Burkholderia pyrrocinia CAB08106-4. Res. Plant Dis. 19:21-24.

Howarth, F. G. 1991. Environmental impacts of classical biological control. Annu. Rev. Entomol. 36:485-509.

Hsu, S. and Lockwood, J. 1975. Powdered chitin agar as a selective medium for enumeration of actinomycetes in water and soil. J. Appl. Microbiol. 29:422-426.

Huh, E. J. and Kim, J. W. 2010. Consumer knowledge and attitude to spending on environment-friendly agricultural products. Korean J. Hum. Ecol. 19:883-896.

Idris, E. E., Iglesias, D. J., Talon, M. and Borriss, R. 2007. Tryptophan-dependent production of indole-3-acetic acid (IAA) affects level of plant growth promotion by Bacillus amyloliquefaciens FZB42. Mol. Plant-Microbe Interact. 20:619-626.

Jang, M. R., Moon, H. K., Kim, T. R., Yuk, D. H., Kim, J. H. and Park, S. G. 2010. Dietary risk assessment for pesticide residues of vegetables in Seoul, Korea. Korean J. Nutr. 43:404412.

Jeon, S. Y., Kim, Y. G., Lee, S. M., Son, H. J., Park, H. C., Kim, S. T., Park, K. D., Kang, U. G. and Kim, K. K. 2010. Structural identification of antibiotics from Pseudomonas sp. RRj 228, a antifungal activity of Collectotrichum acutatum causing anthracnose on pepper. J. Life Sci. 20:1254-1260.

Jung, M. K. and Oakley, B. R. 1990. Identification of an amino acid substitution in the benA, $\beta$-tubulin gene of Aspergillus nidulans that confers thiabendazole resistance and benomyl supersensitivity. Cell Motil. Cytoskeleton 17:87-94.

Keel, C., Schnider, U., Maurhofer, M., Voisard, C., Laville, J., Burger, U., Wirthner, P., Haas, D. and Défago, G. 1992. Suppression of root diseases by Pseudomonas fluorescens CHA0: importance of the bacterial secondary metabolite 2,4-diacetylphlorogluciniol. Mol. Plant-Microbe Interact. 5:4-13.

Kegley, S., Neumeister, L. and Martin, T. 1999. Disrupting the balance: ecological impacts of pesticides in California, pp. 7-65. Pesticide Action Network, North America.

Kim, B. S., Oh, H. M., Kang, H. J., Park, S. S. and Chun, J. S. 2004. Notes: Remarkable bacterial diversity in the tidal flat sediment as revealed by $16 \mathrm{~S}$ rDNA analysis. J. Microbiol. Biotechnol. 14:205-211.

Kim, H. G. and Nam, M. H. 1999. Anthracnose of strawberry in Korea. Res. Plant Dis. 5:8-13.

Kim, J. H., Lee, S. H., Kim, C. S., Lim, E. K., Choi, K. H., Kong, H. G., Kim, D. W., Lee, S. W. and Moon, B. J. 2007. Biological control of strawberry gray mold caused by Botrytis cinerea using Bacillus licheniformis N1 formulation. J. Microbiol. 
Biotechnol. 17:438-444.

Kim, J. T., Park, S. Y., Choi, W. B., Lee, Y. H. and Kim, H. T. 2008. Characterization of Colletotrichum isolates causing anthracnose of pepper in Korea. Plant Pathol. J. 24:17-23.

Kim, S., Park, M., Yeom, S. I., Kim, Y. M., Lee, J. M., et al. 2014. Genome sequence of the hot pepper provides insights into the evolution of pungency in Capsicum species. Nat. Genet. 46:270-278.

Kim, S. T. and Yun, S. C. 2011. Biocontrol Activity of Myxococcus sp. KYC 1126 against Phytophthora blight on hot pepper. Res. Plant Dis. 17:121-128.

Kim, T. S., Lee, G. H., Kim, G. J., Lee, S. W., Park, K. S. and Park, J. W. 2010. Antifungal activity of bacterial strains isolated from tidal mudflat and salted seafood (traditional jeotgal) against six major plant pathogens. Korean J. Pestic. Sci. 14:421-426.

Kim, Y. K., Hong, S. J., Shim, C. K., Kim, M. J., Choi, E. J. Lee, M. H., Park, J. H., Han, E. J., An, N. H. and Jee, H. J. 2012. Functional analysis of Bacillus subtilis isolates and biological control of red pepper powdery mildew using Bacillus subtilis R2-1. Res. Plant Dis. 18:201-209.

Kloepper, J. W., Leong, J., Teintze, M. and Schroth, M. N. 1980. Pseudomonas siderophores: a mechanism explaining diseasesuppressive soils. Curr. Microbiol. 4:317-320.

Kloepper, J. W., Ryu, C. M. and Zhang, S. 2004. Induced systemic resistance and promotion of plant growth by Bacillus spp. Phytopathology 94:1259-1266.

Kong, H. G., Chun, O. J., Choi, K. H., Lee, K. Y., Baek, J. W., Kim, H. G., Murugaiyan, S., Moon, B. J. and Lee, S. W. 2010a. Formulation of Bacillus amyloliquefaciens A-2 and its efficacy to control tomato leaf mold caused by Fulvia fulva. Res. Plant Dis. 16:27-34.

Kong, H. G., Kim, J. C., Choi, G. J., Lee, K. Y., Kim, H. J., Hwang, E. C., Moon, B. J. and Lee, S. W. 2010b. Production of surfactin and iturin by Bacillus licheniformis N1 responsible for plant disease control activity. Plant Pathol. J. 26:170177.

KOSTAT (Statistics Korea). 2013. Available from: http://kostat. go.kr

Kwak, Y. K., Kim, I. S., Cho, M. C., Lee, S. C. and Kim, S. 2012. Growth inhibition effect of environment-friendly farm materials in Colletotrichum acutatum in vitro. J. Bio-Environ. Control 21:127-133.

Lamsal, K., Kim, S. W., Kim, Y. S. and Lee, Y. S. 2012. Application of rhizobacteria for plant growth promotion effect and biocontrol of Anthracnose caused by Colletotrichum acutatum on Pepper. Mycobiology 40: 244-251.

Lee, G. W., Kim, M. J., Park, J. S., Chae, J. C., Soh, B. Y., Ju, J. E. and Lee, K. J. 2011. Biological control of Phytophthora blight and anthracnose disease in red-pepper using Bacillus subtilis S54. Res. Plant Dis. 17:86-89.

Lee, S. Y., Weon, H. Y., Kim, J. J. and Han, J. H. 2013. Cultural characteristics and mechanism of Bacillus amyloliquefacien subsp. plantarum $\mathrm{CC} 110$ for biological control of cucumber downy mildew. Korean J. Pestic. Sci. 17:428-434.

Lee, S. Y., Lee, S. B., Kim, Y. K. and Hwang, S. J. 2006. Biological control of garlic white rot accused by Sclereotium cepivorum and Sclereotium sp. using Bacillus subtilis 122 and Trichoderma harzianum 23. Res. Plant Dis. 12:81-84.

Lim, T. H. 2005. Antifungal activity of Streptomyces griseofuscus 200401 against pathogens causing late blight and anthracnose on pepper. Korean J. Pestic. Sci. 9:102-107.

Mahoney, M. J. and Tattar, R. 1980. Identification, etiology, and control of Euonymus fortunei anthracnose caused by Colletotrichum gloeosporioides. Plant Dis. 64:854-856.

Malik, K. A., Bilal, R., Mehnaz, S., Rasul, G., Mirza, M. S. and Ali, S. 1997. Association of nitrogen-fixing, plant-growthpromoting rhizobacteria (PGPR) with kallar grass and rice. Plant Soil 194:37-44.

Miles, S. and Frewer, L. J. 2001. Investigating specific concerns about different food hazards. Food Qual. Prefer. 12:47-61.

Nautiyal, C. S. 1999. An efficient microbiological growth medium for screening phosphate solubilizing microorganisms. FEMS Microbiol. Lett. 170:265-270.

Ongena, M. and Jacques, P. 2008. Bacillus lipopeptides: versatile weapons for plant disease biocontrol. Trends Microbiol. 16:115-125.

Pal, K. K. and Gardener, B. M. 2006. Biological control of plant pathogens. Plant Health Instructor 2:1117-1142.

Park, K. S. and Kim, C. H. 1992. Identification, distribution and etiological characteristics of anthracnose fungi of red pepper in Korea. Plant Pathol. J. 8:61-69.

Peres, N. A. R., Souza, N. L., Peever, T. L. and Timmer, L. W. 2004. Benomyl sensitivity of isolates of Colletotrichum acutatum and C. gloeosporioides from citrus. Plant Dis. 88:125130.

Raaijmakers, J., Vlami, M. and de Souza, J. 2002. Antibiotic production by bacterial biocontrol agents. Antonie Van Leeuwenhoek 81:537-547.

Rodríguez, H. and Fraga, R. 1999. Phosphate solubilizing bacteria and their role in plant growth promotion. Biotechnol. Adv. 17:319-339.

Rossolini, G. M., Schippa, S., Riccio, M. L., Berlutti, F., Macaskie, L. E. and Thalller, M. C. 1998. Bacterial nonspecific acid phosphohydrolases: physiology, evolution and use as tools in microbial biotechnology. Cell. Mol. Life Sci. 54:833850.

Sahu, S. and Jana, B. 2000. Enhancement of the fertilizer value of rock phosphate engineered through phosphate-solubilizing bacteria. Ecol. Eng. 15:27-39.

Sari, E., Etebarian, H. R. and Aminian, H. 2007. The effects of Bacillus pumilus, isolated from wheat rhizosphere, on resistance in wheat seedling roots against the take-all fungus, Gaeumannomyces graminis var. tritici. J. Phytopathol. 155:720-727.

Schwyn, B. and Neilands, J. 1987. Universal chemical assay for the detection and determination of siderophores. Anal. Biochem. 160:47-56. 
Sokol, P. A., Ohman, D. E. and Iglewski, B. H. 1979. A more sensitive plate assay for detection of protease production by Pseudomonas aeruginosa. J. Clin. Microbiol. 9:538.

Sundara, B., Natarajan, V. and Hari, K. 2002. Influence of phosphorus solubilizing bacteria on the changes in soil available phosphorus and sugarcane and sugar yields. Field Crops Res. 77:43-49.

Teather, R. M. and Wood, P. J. 1982. Use of Congo red-polysaccharide interactions in enumeration and characterization of cellulolytic bacteria from the bovine rumen. Appl. Environ. Microbiol. 43:777-780.

Than, P. P., Del Castillo, C. S., Yoshikawa, T. and Sakata, T. 2004. Extracellular protease production of bacteriolytic bacteria isolated from marine environments. Fish. Sci. 70:659-666.

Vega, K. and Kalkum, M. 2012. Chitin, chitinase responses, and invasive fungal infections. Int. J. Microbiol. 2012:10.

Weller, D. M. 2007. Pseudomonas biocontrol agents of soilborne pathogens: looking back over 30 years. Phytopathology 97:250-256.
Wesseling, C., McConnell, R., Partanen, T. and Hogstedt, C. 1997. Agricultural pesticide use in developing countries: health effects and research needs. Int. J. Health Serv. 27:273308.

Wu, W. S., Wu, H. C. and Li, Y. L. 2007. Potential of Bacillus amyloliquefaciens for control of Alternaria cosmosa and $A$. patula of Cosmos sulfurous (Yellow Cosmos) and Tagetes patula (French marigold). J. Phytopathol. 155:670-675.

Xu, S. J., Hong, S. J., Choi, W. and Kim, B. S. 2014. Antifungal activity of Paenibacillus kribbensis strain T-9 isolated from soils against several plant pathogenic fungi. Plant Pathol. J. 30:102-108

Yang, H. S., Sohn, H. B. and Chung, Y. R. 2002. Biological control of Pythium damping-off of cucumber by Bacillus stearothermophilus YC4194. Res. Plant Dis. 8:234-238.

Yoo, J. H., Park, I. C. and Kim, W. G. 2012. Biocontrol of anthracnose of chili pepper by Bacillus sp. NAAS-1. Korean J. Mycol. 40:277-281. 